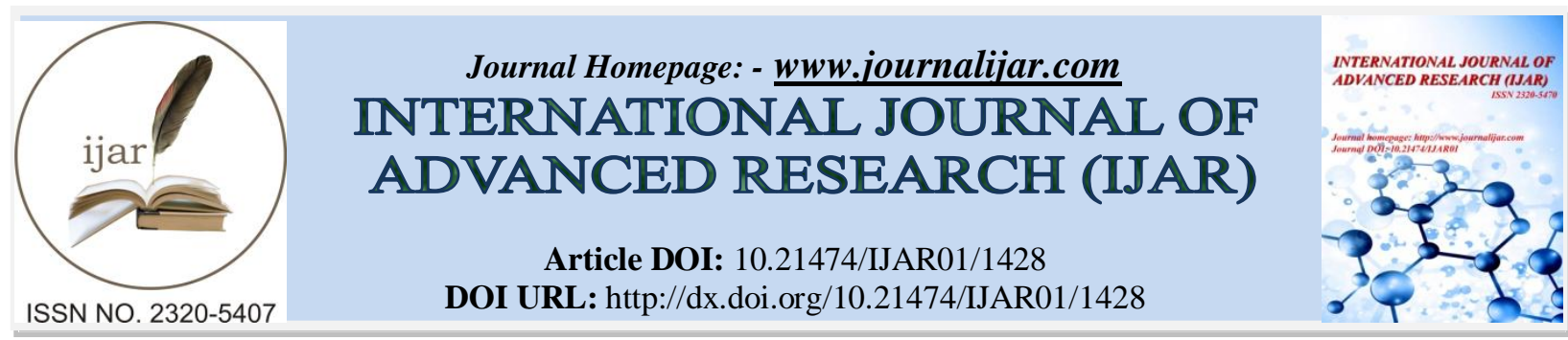

RESEARCH ARTICLE

\title{
RURAL ENTREPRENEURSHIP DEVELOPMENT SCHEMES OF GOVERNMENT:- AN ANALYTICAL STUDY OF KEY SUCCESS FACTORS (WITH REFERENCE TO AJMER DISTRICT).
}

Dr.Nidhika joshi.

Teaching fellow, Center for Entrepreneurship and Small Business Management MDS University Ajmer - 305009, Rajasthan.

\section{Manuscript Info}

Manuscript History

Received: 12 June 2016

Final Accepted: 19 July 2016

Published: August 2016

Key words:-

Key Success Factors (KSF),

Entrepreneurship Development

Programmes (EDP), Volatile

Government Schemes, Entrepreneur

Responsiveness.

\section{Abstract}

Objective:- The paper seeks to understand \& find key success factors for effective and successful implementation of government run Rural Entrepreneurship development programmes / schemes. Paper also seeks to identify the level of dependency of two variables i.e. Volatile Government Schemes and Entrepreneur Responsiveness on each other.

Methodology/Approach:- A primary data is being collected through Questionnaire distribution. A random sample of 30 respondents/beneficiaries of various government run EDP's was selected to respond on the questionnaire. A factor Analysis approach and some statistical regression techniques are proposed to be used to analyse the key success factor/factors and level of dependency of Volatile Government Schemes and Entrepreneur Responsiveness on each other.

Major Findings:- This study is proposed to find the key success factor (having differing criteria priorities \& weight age) like Technical knowhow support, Financial Resources, Education \& Training support, Marketing Support, Market Development, Strategic Alliances \& Partnership of Government \& Private etc., which are to be addressed in the effective implementation process of entrepreneurship development programme. The study also proposes to find the interdependency of Volatile Government Schemes and Entrepreneur Responsiveness for effective strategy formulation.

Implications:- Entrepreneurship is one critical key to employment generation \& creating economic \& social value for our country. An effective formulation and implementation of strategies for entrepreneurial development is essential for all government schemes as it incurs enormous amount of time \& money cost of the nation. Therefore, Governments entrusting on Rural Entrepreneurship for all round growth should identify \& formulate key success factors so as to ensure the desired objective attainment.

Copy Right, IJAR, 2016,. All rights reserved. 


\section{Introduction:-}

Rural development is more than ever before linked to entrepreneurship. Institutions and individuals promoting rural development now see entrepreneurship as a strategic development intervention that could accelerate the rural development process. Furthermore, institutions and individuals seem to agree on the urgent need to promote rural enterprises: development agencies see rural entrepreneurship as an enormous employment potential; politicians see it as the key strategy to prevent rural unrest; farmers see it as an instrument for improving farm earnings; and women see it as an employment possibility near their homes which provides autonomy, independence and a reduced need for social support. To all these groups, however, entrepreneurship stands as a vehicle to improve the quality of life for individuals, families and communities and to sustain a healthy economy and environment.

The entrepreneurial orientation to rural development accepts entrepreneurship as the central force of economic growth and development, without it other factors of development will be wasted or frittered away. However, the acceptance of entrepreneurship as a central development force by itself will not lead to rural development and the advancement of rural enterprises. What is needed in addition is an environment enabling entrepreneurship in rural areas. The existence of such an environment largely depends on policies promoting rural entrepreneurship. The effectiveness of such policies in turn depends on a conceptual framework about entrepreneurship, i.e., what it is and where it comes from.

The State vested with the political right to govern over the sovereign must engage in ensuring prosperity among its citizens. In a harmonious society this is achieved through provision of space to individuals and groups to co-exist with differences, such differences in skills and beliefs constituting the basis of private profit ensuring prosperity. This obligation, however, is difficult to discharge in practice. In nations, such as India, rural underdevelopment and the accompanying poverty of a large section of the population continue to be blight on the narrative of development. As part of the development planning exercise in India, the government has been carrying out direct poverty alleviation programs for over two decades now. The thrust of such programs has been generation of employment in rural areas through State financed Entrepreneurship programs that build up the rural physical infrastructure as well. We argue in this paper that the basic thrust of the program is misplaced. Rural unemployment and poverty is, at its roots, an outcome of deskilling of large parts of the rural population (even the rural elites) or devalorization of the skills that they might still possess (leading to a lack of markets to trade). The structure of the program, we argue, reflects the overall structure of State administration in India. Rule making remains the preserve of the Central bureaucracy, failing to reflect any clear strategy or its implementation. Norms are violated (or deviated) in practice and around such deviations a local macabre economy grows up. Lacking the glory of skills, the accumulation (and ensuing prosperity) of those who benefit from such arrangements fail to strike a chord of harmony. Skills and Entrepreneurship take a back-seat.

This paper deals with the issue of finding the key success factors (having differing criteria priorities \& weight age) like Technical knowhow support, Financial Resources, Education \& Training support, Marketing Support, Market Development, Strategic Alliances \& Partnership of Government \& Private etc., which are to be addressed in the effective implementation process of entrepreneurship development programme.

\section{Literature review:-}

Economic vitality of a country is no doubt a necessary condition for social vitality. Without it other important factors that make living attractive in certain areas, such as education, health, social services, housing, transport facilities, flow of information and so on, cannot be developed and sustained in the area in the long run. As evidence suggests, it is false to assume that socially and economically depressed areas will transform into fast growing areas by injection of external investment funds and external expertise. Without entrepreneurial capabilities which are well developed or potentially available, external funds will be wasted on projects that will not provide long term economic growth. Consequently instead of becoming more and more integrated into other economically and socially rich areas, such areas will become increasingly isolated, depopulated, poorer and therefore less and less capable of attracting people who, given other available resources, would make an impact from a development standpoint.

Entrepreneurial, orientation to rural development, contrary to development based on bringing in human capital and investment from outside, is based on stimulating local entrepreneurial talent and subsequent growth of indigenous companies. This in turn would create jobs and add economic value to a region and community and at the same time keep scarce resources within the community. 
To accelerate economic development in rural areas, it is necessary to increase the supply of entrepreneurs, thus building up the critical mass of first generation entrepreneurs (Petrin, 1992), who will take risks and engage in the uncertainties of a new venture creation, create something from practically nothing and create values by pulling together a unique package of resources to exploit an opportunity. By their example they will stimulate an autonomous entrepreneurial process, as well as a dynamic entrepreneurship, thereby ensuring continuous rural development.

It is important to stress that rural entrepreneurship in its substance does not differ from entrepreneurship in urban areas. Entrepreneurship in rural areas is finding a unique blend of resources, either inside or outside of agriculture. This can be achieved by widening the base of a farm business to include all the non-agricultural uses that available resources can be put to or through any major changes in land use or level of production other than those related solely to agriculture. Thus, a rural entrepreneur is someone who is prepared to stay in the rural area and contribute to the creation of local wealth. To some degree, however, the economic goals of an entrepreneur and the social goals of rural development are more strongly interlinked than in urban areas. For this reason entrepreneurship in rural areas is usually community based, has strong extended family linkages and a relatively large impact on a rural community.

Developing entrepreneurs requires a much more complex approach to rural development than is many times the case in practice. It requires not only the development of local entrepreneurial capabilities but also a coherent regional/local strategy. Evidence shows that where this is the case, individual and social entrepreneurship play an important role in rural economic, social and community development. The top down approach gains effectiveness when it is tailored to the local environment. The second prerequisite for its success is that ownership of the initiative remains in the hands of members of the local community. The regional development agencies that fit both criteria can contribute much to rural development through entrepreneurship.

Other institutions that can make a difference to rural development based on entrepreneurship are agricultural extension services. However, to be able to act in this direction, they too must be entrepreneurially minded. They must see agricultural activities as one of many possible activities that contribute to rural development. They must seek new entrepreneurial uses of land and support local initiative in this respect. While tradition is important it is nevertheless dangerous to be over-occupied with the past, otherwise the rural community may turn into a nostalgiadriven society. Networking between different agencies involved in the promotion of rural development through entrepreneurship, by pooling together different sources and skills, by reaching a greater number of would be entrepreneurs and by assisting a greater number of local entrepreneurial initiatives, can have a much more positive effect on rural development than when each agency is working on its own. Entrepreneurship in rural areas can benefit a lot from the so called strategic development alliances, i.e., partnership among governments or non-profit seeking organizations, universities and the private sector.

To summarise, policy implications for rural entrepreneurship development are:

* Sound national economic policy with respect to agriculture, including recognition of the vital contribution of entrepreneurship to rural economic development;

* Policies and special programmes for the development and channelling of entrepreneurial talent;

* Entrepreneurial thinking about rural development, not only by farmers but also by everyone and every rural development organization; and

* Institutions supporting the development of rural entrepreneurship as well as strategic development alliances.

However, there has not been enough development in this area. One of the reasons can be that management modes used were largely governmental. Those who were charged with the responsibility of rural development were either bureaucrats or technocrats, who were using only the schemes as the motivation for developing entrepreneurs, without providing the necessary training for running an enterprise. Wherever we see on oasis of development in the desert of rural underdevelopment, we can trace an imaginative entrepreneur, who has used the correct mode of management of rural entrepreneurial venture to the best. Entrepreneurship is one critical key to employment generation \& creating economic \& social value for our country. An effective formulation and implementation of strategies for entrepreneurial development is essential for all government schemes as it incurs enormous amount of time \& money cost of the nation. Therefore, Governments entrusting on Rural Entrepreneurship for all round growth should identify \& formulate key success factors so as to ensure the desired objective attainment. 


\section{Research methodology:-}

The study is based on primary data collected from 30 respondents from "KHADI GRAMOUDHYOG PRASHIKSHAN KENDRA" situated in Pushkar City (District - Ajmer).The respondents are taking skill development training under an EDP run by the Kendra. The data was collected on the basis of the questionnaire which was prepared after a detailed literature review on Entrepreneurship \& the impact of Government schemes on the related programmes thereof. A detailed literature review suggested that there are certain areas where concentrated effort is required to establish a concrete strategy \& focus on certain points to successfully implement these government run programmes. Few of the suggestive key factors were Technical knowhow support, Financial Resources, Education \& Training support, Marketing Support, Market Development, and Strategic Alliances \& Partnership of Government \& Private etc.

\section{Findings and Analysis:-}

The data collected from respondents was factor analysed using principal component analysis method with varimax rotation. The resultant factors were identified using Eigen value greater than 1 criterion. The results showed the approximate chi - square value as 223.468 at 153 degree of freedom under the Bartlett's Test of Sphericity which is significant at 0.000 level implying overall significance of correlation matrix.

The Kaiser - Meyer - Olkin measure of Sampling Adequacy was 0.512 for the respondent which is sufficiently large. Thus, factor analysis may be considered appropriate for analysing the data. Further analysis was therefore carried out. In the final results, total 7 factors out of 18 from the survey have been extracted. Respondents were asked to rate the key success factors of Government run Entrepreneurship programmes on five point scale.

\section{Customer survey Results:-}

KMO and Bartlett's Test.

\begin{tabular}{|l|l|r|}
\hline Kaiser-Meyer-Olkin Measure of Sampling Adequacy. & .512 \\
\hline Bartlett's Test of Sphericity & Approx. Chi-Square & 223.468 \\
\hline & Df & 153 \\
\hline & Sig. & .000 \\
\hline
\end{tabular}

Total Variance Explained

\begin{tabular}{|l|r|r|r|r|r|r|r|r|r|}
\hline Component & \multicolumn{3}{|c|}{ Initial Eigen values } & \multicolumn{3}{c|}{$\begin{array}{c}\text { Extraction Sums of Squared } \\
\text { Loadings }\end{array}$} & \multicolumn{3}{c|}{$\begin{array}{c}\text { Rotation Sums of Squared } \\
\text { Loadings }\end{array}$} \\
\hline & Total & $\begin{array}{c}\text { \% of } \\
\text { Variance }\end{array}$ & $\begin{array}{c}\text { Cumulative } \\
\%\end{array}$ & Total & $\begin{array}{c}\text { \% of } \\
\text { Variance }\end{array}$ & $\begin{array}{c}\text { Cumulative } \\
\%\end{array}$ & Total & $\begin{array}{c}\text { \% of } \\
\text { Variance }\end{array}$ & $\begin{array}{c}\text { Cumulative } \\
\%\end{array}$ \\
\hline 1 & 4.608 & 25.600 & 25.600 & 4.608 & 25.600 & 25.600 & 3.548 & 19.712 & 19.712 \\
\hline 2 & 2.048 & 11.376 & 36.976 & 2.048 & 11.376 & 36.976 & 2.287 & 12.704 & 32.416 \\
\hline 3 & 1.671 & 9.284 & 46.260 & 1.671 & 9.284 & 46.260 & 1.807 & 10.039 & 42.455 \\
\hline 4 & 1.602 & 8.902 & 55.163 & 1.602 & 8.902 & 55.163 & 1.616 & 8.976 & 51.431 \\
\hline 5 & 1.405 & 7.807 & 62.970 & 1.405 & 7.807 & 62.970 & 1.581 & 8.784 & 60.215 \\
\hline 6 & 1.198 & 6.658 & 69.628 & 1.198 & 6.658 & 69.628 & 1.399 & 7.770 & 67.985 \\
\hline 7 & 1.074 & 5.967 & 75.594 & 1.074 & 5.967 & 75.594 & 1.370 & 7.609 & 75.594 \\
\hline 8 & .963 & 5.351 & 80.945 & & & & & & \\
\hline 9 & .793 & 4.403 & 85.349 & & & & & & \\
\hline 10 & .701 & 3.896 & 89.244 & & & & & & \\
\hline 11 & .526 & 2.924 & 92.168 & & & & & & \\
\hline 12 & .416 & 2.311 & 94.479 & & & & & & \\
\hline 13 & .311 & 1.725 & 96.204 & & & & & & \\
\hline 14 & .232 & 1.291 & 97.495 & & & & & & \\
\hline 15 & .190 & 1.055 & 98.550 & & & & & & \\
\hline 16 & .125 & .692 & 99.242 & & & & & & \\
\hline 17 & .077 & .427 & 99.669 & & & & & & \\
\hline 18 & .060 & .331 & 100.000 & & & & & & \\
\hline
\end{tabular}

Extraction Method: Principal Component Analysis 
Descriptive Statistics.

\begin{tabular}{|l|r|r|r|}
\hline & Mean & Std. Deviation & \multicolumn{1}{c|}{ Analysis N } \\
\hline Eradicating Employment & 3.6000 & .85501 & 30 \\
\hline Economic Independence & 3.4333 & .67891 & 30 \\
\hline Changes in Government & 3.4667 & .77608 & 30 \\
\hline Government Set up & 3.6667 & .71116 & 30 \\
\hline Initial capital \& Market Risk & 3.6333 & .76489 & 30 \\
\hline Individual Attention & 3.1333 & .86037 & 30 \\
\hline Operating Hours & 3.2000 & .80516 & 30 \\
\hline Problem Solution & 3.3667 & .49013 & 30 \\
\hline Sessions by Expert & 3.4333 & .72793 & 30 \\
\hline Skill Development & 2.8667 & .73030 & 30 \\
\hline Customer \& Market knowledge & 3.3333 & .88409 & 30 \\
\hline Advertising \& Marketing Skills & 3.2333 & .77385 & 30 \\
\hline Market Development \& Identification & 3.0333 & .85029 & 30 \\
\hline Selling Skills \& sales enhancement & 2.9333 & .82768 & 30 \\
\hline Financial Support & 3.2667 & 1.11211 & 30 \\
\hline Sources of Finance & 3.4667 & .68145 & 30 \\
\hline Credit on timely basis & 2.9333 & 1.25762 & 30 \\
\hline Sufficient financial Support & 3.2333 & .62606 & 30 \\
\hline
\end{tabular}

The results thus imply that the government should focus on below mentioned factors for effective implementation of Rural Entrepreneurship Development schemes \& its objectives thereof -

1. Unemployment eradication should be the prime objective of these schemes.

2. These schemes should give Economic independence to the entrepreneur.

3. The change in the Government affects the effectiveness of these schemes.

4. The changes in the bureaucratic set up affects the impact of these programmes.

5. Government partnership in business can reduce initial capital \& market risk.

6. These Govt. Programmes should give Individual attention to everyone.

7. Operating hours of these programmes should be convenient to everyone.

There are certain factors like financial support $\&$ credit on timely basis where the standard deviation is very high due to the small sample size so any conclusive remarks cannot be made regarding these factors.

\section{Conclusion:-}

The study is an attempt to reveal the fact that if the Government strategically implement the rural entrepreneurial development programmes the chances of their success and objective attainment are very high. With emphasis on the above mentioned seven points government can motivate people to become successful entrepreneur and can also effectively address the issue of unemployment and sustained growth of all sectors of the economy \& all classes of the society. These schemes should have a sustained implementation cycle with continuous capital, skill, training \& other related factors inflow without being affected by any bureaucratic or government change.

This study emphasises that unemployment eradication should be the prime objective of these schemes. These schemes should give Economic independence to the entrepreneur. The changes in the Government \& Bureaucracy should not affect the effectiveness of these schemes. Government partnership in business can reduce initial capital \& market risk. These Govt. Programmes should give Individual attention to everyone \& operating hours of these programmes should be convenient to everyone. 


\section{References:-}

1. Hisrich, R.D. and, C. Brush (1984) 'The Women Entrepreneurs: Management Skills and Business Problems'. Journal of Small Business Management, 22, pp. 30-37.

2. Petrin, T. (1992). 'Partnership and Institution Building as Factors in Rural Development', paper presented at the Sixth Session of the FAO/ECA Working Party on Women and the Agricultural Family in Rural Development, Innsbruck, Austria, 13-16 October.Stevenson, H.H, et al. (1985). New Business Ventures and The Entrepreneur. Homewood, IL: Irwin.

3. Timmons, J.A. (1989). The Entrepreneurial Mind. Andover: Brick House.

4. Hopkins, M. 2007 'Corporate social responsibility and international development: is business the solution?'

5. Kasturi Rangan, V., 2005. 'Business solutions for the global poor: creating social and economic value' Conference on Global Poverty: Business Solutions and Approaches, Harvard University.

6. Gupta, A. (1992), 'The Informal Education of the Indian Entrepreneur', JSBE, 9(4), pp63-70.

7. Gupta, S. K. (1989), ‘Entrepreneurship Development: The Indian Case', JSBM, 27(10), pp67-69.

\section{Websites:-}

1. www.ssrn.com

2. www.googlescholar.com

3. www.eru.org.in

4. www.nal.usda.gov 